\title{
Jesus - His Transforming Effect
}

\author{
Paul Bharathi \\ MMI College of Theology, Chennai, India \\ Email:paul.bharathi10@yahoo.com
}

\begin{abstract}
Transformation of an individual and the society at large is the sole objective of Jesus' message to his disciples, and in turn, his disciples too preached on the same theme to the believers of Jesus. The first part of the presentation highlights interpreting and understanding Jesus basing on the gospels. The gospels help us to understand Jesus in our own situation and give meaning to our life. As a result, transforming oneself is the most important and meaningful message we learn from the gospels for our life. The second part of the presentation shows how he plays a transformative role in his disciples' lives, and it also gives us an invitation to transform ourselves in our present life. But when we analyze the reality, the believers/disciples are not transformed, rather they remain the same, and their life does not correspond to the teachings of Jesus. They are more preoccupied with observing the rituals and rubrics than following the teachings of Christ in their lives. The third part of the presentation suggests three corrective measures to be taken by every disciple of Jesus, enabling us to transform ourselves and thus live a meaningful life.
\end{abstract}

Keywords: Jesus, Transforming oneself, Externalization, Internalization, Discipleship

\begin{abstract}
Abstrak: Paper ini mengajukan tema transformasi hidup individual dan societas sebagai tujuan dari pewartaan Yesus kepada para murid-Nya dan selanjutnya pewartaan para murid kepada mereka yang beriman kepada Yesus. Bagian pertama menguraikan dan menginterpretasi pewartaan Yesus dalam Injil. Dari Injil kita mengerti bahwa transformasi diri merupakan pesan penting Yesus sendiri. Bagian kedua mempresentasikan bagaimana Yesus berperan pada transformasi hidup para murid dan selanjutnya transformasi hidup kita sendiri. Tetapi, dalam kenyataan transformasi diri sebagaimana dikehendaki oleh Yesus dalam Injil itu tidak mudah. Alasannya, hidup mereka kerap lebih terpaku kepada ritualisme dan rubrik daripada mengikuti ajaran Kristus sendiri. Bagian ketiga mengusulkan tiga kriteria korektif yang harus diambil agar kita mampu mentransformasi diri kita dan dengan demikian menjalani hidup selaras dengan Injil.
\end{abstract}

Kata kunci: Yesus, Transformasi diri, Eksternalisasi, Internalisasi, Pemuridan

\section{Introduction}

My purpose in this article is to highlight Jesus' transformative effect on the life of his disciples and believers. Jesus' purpose in coming into this world was to transform each individual and through them the world as a whole, and his teachings and his deeds were oriented in this direction. During his time, where a change was needed both at religious and social level, Jesus emphasized the transformation of people. He observed that many people were religious but not spiritual, in the sense that they were following all the religious practices meticulously without understanding the deeper meaning of those practices. As a result, there was no qualitative change in their lives. Their lives were not exemplary as required by Judaic law. Jesus explicitly mentioned this on several occasion to the people of his time and demanded that they change. He pointed out in his parables and teachings that they were more concerned with external observance of the law, but not open to change internally. The prophets in the Old Testament taught similarly, inviting the people of their time to change themselves. As prophet Joel 
beautifully puts it, "rend your hearts and not your clothing" (Joel 2:13). He says there is no use in external ritual observances unless they also represent a deeper spiritual transformation.

My reflection in this article results from one question: why don't we change? Why is there no transformation in our lives even though we read the Bible every day and attend Holy Mass, but they don't have any transformative effect on us. When we analyze our present situation, we, as Christians appear to be more concerned with rubrics and rituals, at the same time neglecting the teachings of Jesus which would bring change in us. This article reminds us that the teachings of Jesus and following his footsteps are more important than the rituals and rubrics. I am not trying to do away with the rituals but rather attempting to show that the purpose of rituals is to help us reach the next stage of following Jesus which involves both learning and putting into action the teachings of Jesus, instead of simply being satisfied with observing the signs and symbols. We need to transcend those symbols and experience the ultimate reality. In this article, I suggest some corrective measures to be taken in terms of our approach and understanding with regard to our today's religious practices (especially in Asian landscape's experience) and the teachings of Jesus.

\section{Methodology}

The method that is adapted in this article to drive home the message of transformation is simple and practical. We can approach the gospels in different ways to arrive at the meaning. There are scholarly approaches where we study a particular narrative in the gospels in a scientific way, in the sense of delving into the historical background of the text, studying the etymological aspect of particular words in the text or trying to give a hermeneutical interpretation of the text. This scientific study of the biblical text will certainly help us to attain a higher degree of knowledge on the Bible, but in no way, it helps us to transform our lives. Therefore, a practical and pastoral approach is needed towards the biblical texts for our own lives. This approach makes the word of God more relevant and meaningful for us. "Some of the practical purposes the Bible aims to achieve are: (i) It points people to Jesus (ii) It builds a relationship with God (iii) It equips for life's battle (iv) It guides our conduct of life" (Panackel, 2016, p. 192). The practical application of the word of God helps us to change our lives in totality and brings in us a better relationship with God through Jesus and within ourselves as well. The aim of this article is to highlight on the theme of transformation by interpreting the gospels and applying it to our practical life. In the gospels Jesus too aims at the transformation of individuals and the society at large. To emphasize on this theme, Jesus takes simple examples from our own lives and interprets it. This article takes all those words of Jesus in the gospels where he emphasizes on the theme of transformation and tries to apply them in our lives, so that we too may be transformed.

\section{Interpreting and understanding Jesus in our life}

The bible is open to readers in the sense that although it was written centuries ago in a different, historical, social, and cultural set up, contemporary readers can find answers to all the problems, issues, and challenges facing. In the bible, the gospels which contain Jesus' life and his words, are accessible to us for understanding and resolving the issues of today's world. When we read the gospels, we understand them from our own perspective. For example, when we undergo a lot of suffering in our lives, we read the gospel from the perspective of suffering; and find solace, comfort, and tranquility in the gospels. The gospel provides meaning for our lives when we search for it. Because the scripture is 
so open, anyone who wants strength or meaning in their life can find it regardless of their own unique situation in which he/she lives.

The four gospel writers provide their interpretation of the Jesus-event in their own context in order to make it relevant and meaningful for their community. The Gospels are theological works which interpret and re-interpret the message of Jesus for concrete situations with the aid of historical reminiscences. The gospel writers addressed the issues and problems of their respective communities through their interpretation of the Jesus-event. The gospels tell us that we need to make Jesus and his message relevant and meaningful for our own lives. Therefore, we look for the relevance of the Christevent for today's world to give meaning to and to touch our lives, and, in so doing, become efficacious.

What is most disturbing is that we can remain unchanged, untransformed in spite of the fact that we have received and participated in the sacraments. We need to understand and interpret Jesus and his message because this can have a transformative impact on our lives. This is the relevance and meaning of the Jesus-event. Accordingly, we need to understand Jesus and deepen our knowledge of him which will certainly impact our lives.

The gospels are obviously narratives about the life, death, and resurrection of Jesus. When we read the gospels, we are aware from the start of each of these narratives that the main character is not simply an admirable figure from the past but rather the one believed to be now alive and powerfully present in the community. "The words and deeds of his past are given deep resonance by the sounding board of the first Christians' present experiences and convictions. They could not help finding something of their story in his, for with his resurrection, they saw him as active in their lives" (Johnson, 2009, p. 158). Therefore, first and foremost, we need to understand that Jesus is not only alive and actively present in our lives but also, he is guiding and directing our thoughts, decisions, and our life in totality.

Each gospel presents Jesus in different ways. For example, the gospel of John presents Jesus as the one who pre-existed with God and became a human person. According to this gospel, Jesus asserts his divine origin more than his human origin whereas other gospels demonstrate both Jesus' divine and human origin. Among the synoptic gospels there are differences in portraying the nature of Jesus. As I mentioned earlier, we interpret Jesus in our own context and make him relevant for us. Jesus becomes more relevant when he is understood in relation to our life situation. Life is not to be wasted rather it is to be lived meaningfully. Our life should be like the seed that fell on the good soil which produced a hundredfold. It should be like the man who was given ten talents and traded thereby doubling them. What these parables teach us is that our life should be meaningful and fruitful. Only when our life is successful does it become meaningful, but success does not mean having more money, power, or wealth. Success means living and doing things for others, and in this way our life becomes meaningful and provides satisfaction and happiness. Jesus taught us to be always other-centered rather than selfcentered, and such a life gives us meaning, happiness, and satisfaction. In order to live such a life, we need to be transformed and changed from self-centered to other-centered and God-centered. When we experience Jesus' presence within us, when we experience Jesus as present, guiding and directing us, certainly we can change ourselves.

To have such an experience, we have to relate to Jesus as a person, delve into the life, personality, character and nature Jesus as portrayed in the gospels. We need to relate the events that took place in the lives of Jesus, the messages that he gave, the stories that he narrated, the parables that he told, to our own lives since all of them have the power to influence our lives, and transform us. 
The problem is that we cultivate a great devotion to Jesus, but forget his life-story that tells us how to live and to behave in this world. We need to change our approach. We should not only focus on the Jesus who is above in heaven. We should first think and reflect on the Jesus who lived on this earth like any of us, who walked, talked, and ate with people and also contemplate his message. Only then should we move to the Jesus who is above in heaven, as second person of God. Then, his message and life will touch our lives.

It is paramount that we relate to Jesus who is present and active in our life. We need to understand Jesus who was like one of us and lived a meaningful life by orienting his life toward God and others. Sometimes, our problem is that we overemphasize the dogmas about Christ and forget the human aspect of Jesus. Dogmas are fundamental to our faith, no doubt about it, but sometime or even most of the time, our faith becomes static, not dynamic due to dogmatic faith. "Dogma and theology have often presented Jesus as one "whose manhood has been blotted out" by the glory of his Divinity; or as one "who shares our essence but not our existence"; or one who possesses our nature but none of its problems, its history, its experience. It is an over-spiritualized Christ, a Christ in the clouds, a de-contextualized alien to our earth, foreign to every human reality, and far removed from the world of our need and endeavors" (Rayan, 1999, pp. 196-207).

"The flesh of Jesus is to free our faith from gnostic and docetic tendencies, and convert it into discipleship and historical practice. An important task of theology today and all Christian communication is to convince the faithful that God's son is truly a man among men and not God merely appearing as a man. In effect, we must not begin by saying Jesus is God, as if we already knew what Godhead is all about. We must not begin with "a truth" but with a human life, its events, experiences and vicissitudes. And then attend to their significance and to the further, deeper realities they reveal" (Rayan, 1999, pp.196-207). We are to move from the immanent aspect of Christ to transcendental aspect of Christ, not the other way. We need to change our approach towards Christ, moving from human realities to divine realities. "The gospels are narrative Christology, which spell out for us in story and saying the significance the Jesus-experience in its totality- his life, death and resurrection-had for the evangelists and their communities" (Soares-Prabhu, 2015, p. 67).

There is a fundamental difference between the dogma of Jesus and the flesh of Jesus. We need to balance both in our faith life. Overemphasizing one at the cost of the other, will lead us either to a static life and fundamentalism, or it will endanger our faith life. Integrating both aspects of Jesus will enable us to see Jesus in a more holistic way and as active in our lives, experiencing his touch in every aspect of our life and experiencing him in sacraments as well. The result will be a dynamic life which will enable us to understand Jesus and his message in each and every situation of life, witnessing his impact on our lives and eventually being transformed and changed.

\section{Jesus -his transformative role}

Jesus plays a transformative role in our lives, and I present him as a transforming leader, because he has the power to transform people. When he called his first disciples who were busy catching fish, he called them and said, "I will make you fish for people" (Mt 4:19b; Mk 1:17b), "from now on you will be catching people" (Lk 5: 10b). With these words, Jesus clearly says that he is going to transform his disciples from ordinary people to extraordinary people. In addition to this transformative quality, Jesus had other qualities too to attract and transform people. He was creative and innovative in his mode of communication. He was energetic and enthusiastic in entering into relationships with people, especially 
with the marginalized. He was mission and vision oriented. All these features indeed made Jesus a leader who could transform people.

In today's world, sometimes leader refers to a political leader who unleashes his power in terms of money and muscle to coerce people to follow. Leadership in a broad sense, any leader, whether spiritual, political or social, influence people with their teachings and with their way of life to bring change in others' lives. Jesus certainly did the same. He brought changes in the lives of millions of people across the world. His teachings and his life are still relevant today and continue to influence people. "Transforming leaders are the one who create ripple effects as they practice what they have learned wherever they go" (Pearson, 2012, p. 2). Jesus had a significant impact on his disciples and other people with his message. The book titled as "Love Like Jesus", authored by Paul E Miller, says that we need to study Jesus as person, a person who loves, cares, forgives, and shows compassion to others, a person who establishes a genuine relationship with others regardless of their status. He tries to describe the personality of Jesus in his book and urges us to imitate Jesus' personality in our life, so that we can lead a true Christian life.

"The transforming leader by inspiring others with a larger vision that brings out the best in them and produces positive transformational outcomes" (Pearson, 2012, p. 16). Jesus as a transforming leader did inspire others, especially his disciples with his vision of establishing the kingdom of God, and after his resurrection, there was a positive transformation in the lives of his disciples, although the process of transformation began during his earthly ministry. Jesus as transformational leader seeks to motivate followers by transforming their conception of self and their private goals to coincide with the larger vision of the leader which takes into consideration the good of society and the world as a whole. The disciples' conception of self was based on their early profession, i.e., fishermen, and Jesus changes it and broadens their vision in the context of the Kingdom of God.

Jesus' life and his message is transformative and can influence our life. It all depends on how we interpret his life and apply that to our life. There are various ways we can interpret it. Even each gospel interprets it in a different way. There are different approaches to the Christ-Event. Each preacher interprets it differently even though belonging to the same church. Consider the interpretations of the preachers of different churches. I have heard remarkably different interpretations by a variety of preachers of the same gospel passage. The very same Jesus is understood in various ways. Each one interprets according to his/her situation and according to his/her need. We might see as more authentic and acceptable those interpretations which give meaning to our own life situation. And that meaning has to touch a person's life and it must have some impact on the person. In other words, it should transform us. It does transform persons as it touches the lives of a lot of people. A person can be touched by hearing the preaching of charismatic preachers or pastors, or by reading the scripture and doing self-reflection or by reading some books on Jesus.

Accepting Jesus and his message will effect transformational change that requires closing the gap between what we want, what we are, and what we do. Thus, if you want to make significant and longlasting changes, we must look within before we look without. "By bringing our inner world (our thought process, perspectives, self-awareness, emotional intelligence, capacity for staying centered in the midst of turmoil) into alignment with our outer world (our actions, how we lead, how we live the work, how we work with people)" (Pearson, 2012, p. 2). Transformation is a process that takes place first within and then our actions need to correspond with our inner world. Both our thoughts and actions need to be in synch. 
Another way to look at Jesus is as a Liberator who transforms our lives from the slaveries of sin, prejudices, biases, jealousy, and a discriminatory mindset. This interpretation is mostly based on human aspirations, human feelings, and human need. It is more liberative in the sense that it can liberate you from your slavery, both internal and external. Human beings are not only spiritual beings and so we should not stress only our spiritual dimension but rather consider the whole aspect of the human person and human development, social, economic and spiritual. I have seen people apply only the spiritual dimension of Jesus to their lives. The result is a life centered around only spiritual activities, neglecting other responsibilities to society and to family, failing to reaching out to the needy, both in the society in which they live and in the family to which they belong. Ultimately, they evade their responsibility to be a catalyst of change in society. As a result, they are not able to effect any change or transformation in their own lives. Unless we effect a change in ourselves, we can't work for change in others. As Mahatma Gandhi said, "You must be the change you want to see in the world". If you want to see change in others, first and foremost, each one individually has to change. The main focus of Jesus' message is on the personal conversion of each one. He says, "Repent, for the Kingdom of God has come near" (Mt. 4:17). The word "repent", in Greek "metanoia", means change, a change of life, a change of one's values, a change of one's belief system, a change of thinking. It is a complete and radical turnaround from a former way of life to a new way of life.

Why are there no changes in the lives of Christians? Why is there no transformation in the lives of so-called "Christians", even including in the lives of priests and religious. The are many reasons. Swami Vivekananda, when he spoke in Chicago said: "Go back to Christ who had no place to lay his head". What he meant was, we should go to the root of the teachings of Jesus, understand it and practice it, nothing else. The crux of our problem is that we are at the superficial level in terms of understanding the teaching of Jesus, not at the deeper level. We are more into ritual levels which are only signs and symbols, pointing to the reality of Christ, but we have failed to travel beyond that, failed to transcend to a higher realm i.e., reality. As a result, we are satisfied with the mere following of rituals rather than following the teaching of Jesus. In fact, Jesus was against this attitude of the Pharisees, who were more interested in practicing the rituals than understanding and practicing the core message of Judaism, i.e., love one another. We all fall into the same trap, not realizing what we do is completely contrary to what Jesus taught us. What should we do in order to go to the root of the teaching of Jesus? What should be our approach?

\section{From externalization to internalization}

The central theme of Jesus' preaching was the "Kingdom of God," and he did not define this concept in an unambiguous way. Rather, he explained it implicitly through his teachings and deeds. He did not give a set of doctrine or rituals and sacrifices to follow, rather he gave only one commandment i.e., "Love of God and love of neighbor. Through his teachings, we can practice both love of God and love of neighbor, by internalizing them. We need to understand the context in which Jesus insisted on the need for internalization. We use lot of signs and symbols in our rituals, sacraments, and in our daily practices of devotion in our Christian life. Each symbol and sign has meaning and significance. Some people are aware of those meanings but fail to internalize them, or some people may not be aware of the meaning, and simply perform a routinized practice. We can become satisfied with some devotional and pious acts, such as touching the statue of Jesus, lighting candles, garlanding the statues, and saying some written prayers glibly. As a result, Jesus' life does not have any impact on us. On the contrary, we 
remain the same in spite of being religious. Being religious will not help us. Jesus was not religious, but spiritual. We need to change our approach towards Jesus and our understanding of Jesus. Our pious activities can result in self-complacency or be motivated for showing off for others. We need to reflect on and consider, even question our motivation in following religious practices. Our motivation should be to follow Jesus in our life and to live a life like Jesus, nothing else. Jesus was opposed to this attitude of self-complacency and showing off to others in our religious practices. Self-complacency leads one to self-righteousness, concluding that "I am right and you are wrong attitude", because I follow all the religious practices, and showing off to others leads one to self-centeredness, not God-centeredness. Selfcentered people expect that others should praise and respect them because they are religious. The Pharisees and Sadducees and the so-called religious during Jesus' time had this attitude. Jesus was against it. We have the same problem. We are not that different from the Pharisees and Sadducees of Jesus' time. We need to analyze why such situations existed at the time of Jesus and how Jesus handled those situations.

Judaism, which emerged from a post-exilic background, emphasized the "Torah" (Law) which means "Commandment". When the Lord chose the people of Israel out of all other people on the earth, he showed himself as a God of faithfulness and loving kindness (Ex. 34:6). The covenant he made with Israel demanded the same qualities of them. So, the Deuteronomic law became central to the Judaism, what we call "Shema Israel", Love your God with all your hearts, with all your mind...(Dt. 6:4-5). This law demands that they were to be faithful to the Lord and not turn away to other gods; they were also to show covenantal love to one another, as Lev. 19:18, says, "You shall love your neighbor as yourself". Jesus too articulates the same in his teaching, insisting on these two commandments as the greatest commandments of all (Mt. 22:34-40, Mk 12:28-34, Lk 10:25-28). By observing these laws, Israel was to be a "holy nation" (Ex. 19:6), different from other peoples on the earth; "you shall therefore be holy, for I am holy" (Lev. 11:45). This aspect of the holiness of the commandment, however, became increasingly problematic: what did being holy demand?

After the exile, with the rebuilding of the second temple, the Judaic religion became more institutionalized with the institution of priesthood, many of the rituals, sacrifices and other religious practices such as observance of Sabbath, and purity rituals. And with the emergence of different sects, like Pharisaic groups, Sadducees and Essenes, all those purity rituals and sacrifices were meticulously followed, not only by these groups but they also wanted others to follow them in a strict manner. For them, to be holy meant to follow all those external practices to attain holiness. And they neglected the main commandments of Deuteronomic law, i.e., the love of God and the love of neighbor. Jesus castigates these attitudes of Pharisees and Scribes in the gospel of Mathew as "woe pronouncements" (Mt. 23:13-30). In these seven woe pronouncements of Jesus, he clearly demonstrates that Godexperience cannot be attained by merely following the rituals in a literal and meticulous way, but rather by internalizing those rituals in one's life and manifesting God's love through love of neighbor which is most important. For example, he says, "woe to you, scribes and Pharisees, hypocrites! For you tithe mint, dill, and cumin, and have neglected the weightier matters of the law; justice and mercy and faith" (Mt. 23:23). In another woe pronouncement, he clearly refers to internalizing religious practices, instead of worrying about the external practice of rituals, "Woe to you, Scribes and Pharisees, hypocrites! For you clean the outside of the cup and of the plate, but inside they are full of greed and self-indulgence. You blind Pharisee! First clean the inside of the cup, so that the outside also may become clean" (Mt. 23:25). On another occasion, Jesus says, "There is nothing outside a person that by going in can defile, 
but the things that come out are what defile" (Mk. 7:15). At the time of Jesus, some people were very concerned with observing the purity laws in order to remain unblemished. "For Jesus, this type of impurity does not defile a person. Ritual impurity on the outside is less important, because it does not defile the heart. It is the "impurity" that comes from inside, which pollutes a person internally and is later expressed in evil words and actions. In accepting God, the important thing is not to avoid external contacts that can contaminate us, but to live with a clean, good heart" (Pagola, 2013, p. 244).

When we follow the rituals externally, without internalizing, the following effects can be expected:

1. Following the rituals in a more rigid way can pave the way for even more rigidity and fundamentalism. We can become satisfied with performing some rituals and feel self-complacent, self-righteous, and obsessed with observing rubrics rather than absorbing the meaning of those rituals.

2. There may be no correspondence with your moral life. Externally observing rituals does not lead to a good moral and social life. A dichotomy can develop between your so-called religious life and your personal life.

The prophet Amos explains this dichotomy that can develop very well. He teaches us to understand religion in the area of interpersonal relationships. Menezes (2005, p. 87) says, "Mere offering of sacrifices and getting involved in sophisticated liturgies with choir and symphony will not bring us closer to God if we leave out neighbor from our horizon. Religiosity without ethics and concern for the neighbor is empty and hollow" (5:22-24). Furthermore, he says that cult and religion are no longer an expression of their lives but have become empty signs of a hollow ritual (Amos 5:26-27). What Amos trying to say is that our participation in rituals and liturgies is meaningless when our moral life does not correspond to the teachings and tenets of the scripture. Jesus too says the same in Mt. 23:23.

\section{From Devotion to Discipleship}

The next step for our transformation is to move away from mere devotion to discipleship. Devotion is needed, and it is one of the ways to express our faith. But it should lead us further to discipleship. Otherwise, it becomes mere lip service to Jesus. We have devotions to different images of Jesus, but the question is do those devotions lead us to discipleship. As the prophet Isiah says, "Because these people draw near with their mouths and honor me with their lips, while their hearts are far from me" (Isa. 29:13).

We read in the synoptic gospels about Jesus calling his first disciples, and all the gospels are unanimous in using the word "follow". In the call narrative, Jesus seeing his prospective disciples says, "follow me" (Mt. 4:19; Mk. 1:17) and the gospels report, saying, they "followed him" (Jesus) (Mt. 4:22b; Mk 1: 20b; Lk 5:11b; Jn 1:37). Jesus invites his disciples to follow him. The invitation to follow him is the invitation for discipleship. The main aspect of discipleship is to learn from a master. "Discipleship is that the aspirant has a willingness of mind and heart to learn and has decided upon master or the source for his learning" (Anthonysamy, 2018, p. 17). There are two aspects to discipleship. One is the disciple chooses his master, and the other is he/she has openness and willingness to learn from the master. One definition of discipleship is that "a disciple is one who attaches himself to a master submitting himself/herself to him with the sole purpose of learning and attaining maturity" (Anthonysamy, 2018, p. 18). Together with learning, the disciple achieves his/her own personal growth. In other words, by learning from their masters, the disciples formed themselves or equipped themselves for their future life. In the gospel tradition, Jesus adds one more dimension to discipleship in addition to 
the aspect of learning, i.e., mission. There is a mission dimension in the discipleship of Jesus' tradition. "In the entire ministry of Jesus, which actually lasted three years, a major project has been the formation of the twelve disciples. It is they who were expected to continue the mission of Jesus in space and time" (Anthonysamy, 2018, p. 18).

Two characteristics emerge from discipleship. One is learning, and the other is doing. Learning is listening to the teaching of a master, active listening not passive listening. Active listening means to receive the message of the master and internalize it. In Jesus' tradition, disciples are supposed to listen actively to the word of God and internalize it. The word of God is intended to sink into the heart of the disciples and take deep root in their hearts and minds, similar to what Jesus says in the parable of the Sower, in which he speaks about the "seeds fell on good soil and brought forth grain, some a hundredfold, some sixty, some thirty" (Mt. 13:8). Therefore, active listening will bring forth fruits in the life of a disciple.

The second aspect of discipleship is the mission. The mission is the outcome of learning from the master. Learning and mission are interlinked in Jesus' tradition of discipleship. In other words, learning from Jesus by his disciples necessarily lead them to mission. Jesus clearly gives a command for mission to his disciples after the resurrection (Mt. 28:18; Mk 16:15; Lk 24:47). Jesus' essential mission was the establishment of the Kingdom of God. And he wanted his disciples to be a vibrant sign of the kingdom accepting and living his kingdom values and, as a result, being dynamic examples for the whole humanity. Discipleship requires continuing the mission of the master. We, disciples of Jesus, are to carry out his mission in our lives. Finally, to sum up, discipleship is learning to attain maturity in one's life, experiencing transformation and continuing the mission of one's master. We, the disciples of Jesus, are to be transformed and to carry out his mission in our lives.

\section{From superficial to profound experience}

All the religions in the world try to show a way to have an experience of God. The aim and bjective of every religion is to help people search for God and to experience God. Thus, religion becomes meaningful. Ancient religions such as Hinduism personified God in nature certain objects through which they tried to experience God. The God-experience is the foundation for every religion. Christianity was born out of the risen Christ-experience. It is the very foundation on which the Christianity was built. First the disciples experienced the risen Christ, and they shared their experience with others, and those who were converted to Christianity also experienced Jesus in different ways, especially in their breaking of the bread and the word of God which brought a complete transformation in their lives (Acts 2:43-47). The main thrust of Christianity is to have the Christ-experience and change one's life.

When we reflect on own lives, we don't see such transformation taking place in our lives, although we do follow all the religious practices. We are religious, not spiritual. Our religious practices keep us at superficial level, because we do all those practices without contemplating their meaning. Contemplation will result in a mystical experience. The mystical experience will help is to find God within. "The Christian mystical tradition is that which speaks of personal experience of God" (Reynolds, 2019, p. 72). It is the awakening of the "Transcendental self" from the "normal self". Once we experience the transcendental self, we will experience God within and without, sensing God's presence both in ourselves and in others too.

We must travel into our inner self and experience God which will bring transformation. To have such a mystical experience, we need to focus on four things; "1) the teaching of Jesus; 2) his experience 
made accessible through the spirit; 3) the living out of Christian life in a community of faith; and 4) the augmentation and substantiation of that faith in lived experience through the Sacraments" (Reynolds, 2019, p. 72). All these four aspects will help us to have such a mystical experience in our lives which will enable us to experience transformation. This mystical experience will enable us to understand that God and God's dynamic energy are present in all, around all, and through all. "We learn to comprehend how this dynamic energy is at work in every moment and every day and every place, and how it is at work in us" (Allen, 2016, pp. 3-10). Finally, this mystical experience or God's presence is a dynamic energy that works in us to bring change and transformation in each and every one of our lives.

\section{Conclusion}

To sum up, we need to deepen our understanding and knowledge about Jesus, and it has to sink deeply into our hearts in order that the teachings of Jesus may bear fruits in our life. We all need transformation and change and to work as a catalyst for change in others as well. The methodology that I propose is very simple and pragmatic. The first thing is we have to move from externalization to internalization. Second, we shall not remain merely devotees of Jesus but his disciples of him deepening our relationship with him. Finally, we have to move from superficial to profound experience in our life, a mystical experience of Christ within us which will effect change and transformation in our lives.

\section{References}

Allen, Marcia. (2016). Leadership- Conversation with the Leadership Conference of Women Religious. Published in Transformation. Edited by Annmarie Sanders. Bangalore: TPI3, pp. 3-10.

Anthonysamy. (2018). Call to Discipleship. Chennai: New Leader Books, Chennai.

Charles, Panackel. (2016). SPEAK, LORD: All About the Bible in Fifteen Topical Articles. Bangalore Kristu Jyoti Publications.

de Menezes, Rui. (2005). Voices from Beyond-Theology of the prophetical Books. Bombay: St. Pauls, Bombay.

Johnson, Luke Timothy. (2009). The Writings of the New Testament: An Interpretation. Bangalore: TPI. Pagola, Jose A. (2013). Jesus-An Historical Approximation. Bangalore: TPI.

Pearson, Carol. S. Ed. (2012). The Transforming Leader: New Approaches to Leadership for the Twentyfirst Century. Noida, India: Harpers Collins.

Rayan, Samuel. (1999). "This Man Jesus", in Selected Writings of Samuel Rayan. Ed., Kurian Kunnumpuram. Pune: JDV, pp. 196-207.

Rynolds, Stefan Gillow. (2019). Living with the Mind of Christ-Mindfulness in Christian Spirituality. London: St. Pauls.

Soares-Prabhu, George M. (2015). Biblical Themes for a Contextual Theology Today (Vol-I). Edited by Isaac Padinjarekuttu. Pune: JDV, Pune. 